\title{
Methodical bases of perceptual mapping of printing industry companies
}

\author{
Pavel Kalinin ${ }^{1, *}$, and Tatiana Burtseva ${ }^{1}$ \\ ${ }^{1}$ Vyatka State University, Kirov, Russia
}

\begin{abstract}
This is to study the methodological foundations of perceptual mapping in printing industry enterprises. This research has a practice focus which affects the choice of its methodological framework. The authors use such scientific research as analysis of cause-effect relationships, synthesis, problem analysis, expert evaluation and image visualization methods. In this paper, the authors present their assessment of the competitive environment of major printing industry companies in Kirov oblast; their assessment employs perceptual mapping enables by Minitab 14. This technique can be used by experts in the field of marketing and branding to assess the competitive environment in any market. The object of research is printing industry in Kirov oblast. The most important conclusion of this study is that in perceptual mapping, all the parameters are integrated in a single system and provide a more objective view of the company's market situation.
\end{abstract}

\section{Introduction}

Modern feature of the business is the cut-throat competition. The increased competition, associated with changes in social and economic development of Russia's economy, leads to the increased interest of entrepreneurs to the competitiveness of the enterprise. Techniques of competitiveness assessment are the most popular in the evaluation and analysis of strategic business development prospects.

In the course of time and due to changes in the environment, any successful brand model may stop meet the changing needs of the market and consumer needs. That is why the company needs to continually evaluate its competitiveness in order to create a unique image, which develop a positive association among consumers and is associated with a particular printing service.

Consumers of enterprises of the printing industry measure brands not only by material benefits, but also by intangible (emotional) benefits. Therefore, the manufacturer must evaluate both of these parameters [1.2] in the measurement of the degree of consumers' perception in the market of services. Methodical and methodological bases of perceptual mapping are discussed in the scientific literature in more details [3-9]. It should also be noted that the printing industry enterprises of the Kirov region are often examined by scientists [10-13].

The literature on the subject proves the relevance of using perceptual mapping in order to assess the competitiveness of the printing industry companies.

The main objective of the work is to analyze the competitiveness of the printing industry with the help of the methodology of perceptual mapping.

\section{Material and methods}

Visualization of the target audience understanding is possible in perceptual mapping, which is constructed by the statistical method of non-metric multidimensional scaling based on the opinions of consumers of printing services.

The authors have developed a perceptual map for 17 printing houses of the Kirov region using the procedure of the factor analysis of questionnaire data of consumers of printing services of the Kirov Region in the program Minitab 14. This map describes the subjective opinion of consumers of printing services of the Kirov region.

In order to define the problem of multidimensional scaling, which includes a specification of objectives, the choice of competing printing houses, we have analyzed 18 brands and 12 brand making elements that affect the perception of the printing house's image. The results are presented in Table. 1.

Table 1. Key elements for determining the brand position.

\begin{tabular}{|c|c|c|c|}
\hline № & Attributes of perception & № & Attributes of perception \\
\hline $\mathrm{X}_{1}$ & Staff qualification & $\mathrm{X}_{7}$ & $\begin{array}{c}\text { Visual level of printing } \\
\text { product quality }\end{array}$ \\
\hline $\mathrm{X}_{2}$ & Management quality & $\mathrm{X}_{8}$ & The range of printing services \\
\hline $\mathrm{X}_{3}$ & Equipment & $\mathrm{X}_{9}$ & The price factor \\
\hline $\mathrm{X}_{4}$ & $\begin{array}{c}\text { Size of constant and loyal } \\
\text { customer base }\end{array}$ & $\mathrm{X}_{10}$ & Innovative technologies \\
\hline $\mathrm{X}_{5}$ & $\begin{array}{c}\text { Reputation (goodwill) of } \\
\text { enterprise }\end{array}$ & $\mathrm{X}_{11}$ & Deadlines of printing order \\
\hline $\mathrm{X}_{6}$ & $\begin{array}{c}\text { Staff motivation to } \\
\text { improve the quality of } \\
\text { goods }\end{array}$ & $\mathrm{X}_{12}$ & Relations with client \\
\hline
\end{tabular}

\footnotetext{
Corresponding author: kalinin_p_a@mail.ru
} 


\section{Results}

According to the results of consumers' survey of the printing industry enterprises on the basis of assessment of 12 elements on a 10-point scale, we obtain expert opinions, which will allow to build a perceptual map in the future (Table 2).

Table 2. Expert opinions for perceptual mapping of printing industry companies.

\begin{tabular}{|c|c|c|}
\hline \multirow[b]{2}{*}{ № } & \multirow{2}{*}{ Printing house } & Elements of perception of printing houses \\
\hline & & \begin{tabular}{|l|l|l|l|l|l|l|l|l|}
$\mathrm{X}_{1}$ & $\mathrm{X}_{2}$ & $\mathrm{X}_{3}$ & $\mathrm{X}_{4}$ & $\mathrm{X}_{5}$ & $\mathrm{X}_{6}$ & $\mathrm{X}_{7}$ & $\mathrm{X}_{8}$ & $\mathrm{X}_{9}$ \\
\end{tabular} \\
\hline 1 & First printing house & 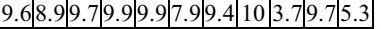 \\
\hline 2 & Kirov regional printing ho & \begin{tabular}{|l|l|l|l|l|l|l|l|l|l|l|l|l|l}
8.5 & 5.6 & 7.1 & 8.6 & 2.1 & 3.8 & 4.6 & 8.7 & 2.4 & 5.1 & 2.9 \\
\end{tabular} \\
\hline 3 & Lona & \begin{tabular}{|l|l|l|l|l|l|l|l|l|l|l|l|}
5.6 & 6.8 & 5.2 & 5.9 & 6.3 & 6.3 & 5.7 & 6.3 & 6.8 & 3.5 & 8.7 \\
\end{tabular} \\
\hline 4 & s & 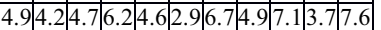 \\
\hline 5 & Servis Print & 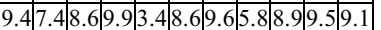 \\
\hline 6 & $\mathrm{rma}$ & \begin{tabular}{|l|l|l|l|l|l|l|l|l|l|l|}
3.9 & 2.1 & 3.1 & 2.3 & 2.1 & 2.5 & 1.8 & 4.6 & 8.7 & 5.2 & 8.9 \\
\end{tabular} \\
\hline \begin{tabular}{|l|l}
7 \\
\end{tabular} & Staraya Vy: & \begin{tabular}{|l|l|l|l|l|l|l|l|l|l|l|}
4.7 & 4.6 & 2.4 & 9.8 & 5.6 & 3.6 & 5.7 & 2.4 & 9.5 & 2.3 & 6.7 \\
\end{tabular} \\
\hline 8 & Raduga & \begin{tabular}{|l|l|l|l|l|l|l|l|l|l|l|}
6.7 & 4.9 & 7.6 & 9.9 & 8.7 & 7.4 & 8.4 & 3.7 & 6.8 & 3.1 & 2.5 \\
\end{tabular} \\
\hline 9 & Printing house of $\mathrm{m}$ & \begin{tabular}{|l|l|l|l|l|l|l|l|l|l|l|}
2.9 & 3.1 & 4.3 & 5.6 & 3.1 & 2.1 & 2.5 & 1.8 & 5.6 & 3.4 & 3.4 \\
\end{tabular} \\
\hline 10 & Funtiko & \begin{tabular}{|l|l|l|l|l|l|l|l|l|l|l|l|l|l|l|l|l|l|l|}
6.1 & 4.6 & 3.8 & 6.3 & 8.7 & 6.8 & 3.7 & 2.8 & 6.3 & 1.9 & 6.7 \\
\end{tabular} \\
\hline 11 & Vyatka-Info & \begin{tabular}{|l|l|l|l|l|l|l|l|l|l|l|}
5.7 & 5.5 & 6.1 & 9.9 & 3.4 & 5.6 & 4.9 & 6.4 & 8.1 & 5.4 & 8.6 \\
\end{tabular} \\
\hline 12 & Printing house of Slo & \begin{tabular}{|l|l|l|l|l|l|l|l|l|l|l|}
4.6 & 4.8 & 4.7 & 6.3 & 2.5 & 6.7 & 4.1 & 5.4 & 5.9 & 2.1 & 6.7 \\
\end{tabular} \\
\hline 13 & Printing house of Kiro & \begin{tabular}{|l|l|l|l|l|l|l|l|l|l|l|}
5.3 & 4.6 & 3.1 & 6.7 & 3.6 & 4.6 & 5.1 & 5.7 & 5.1 & 2.3 & 6.1 \\
\end{tabular} \\
\hline $14 \mathrm{P}$ & Printing house of $\mathrm{K}$ & \begin{tabular}{|l|l|l|l|l|l|l|l|l|l|l|}
5.2 & 3.8 & 2.5 & 5.1 & 2.7 & 7.3 & 3.7 & 3.1 & 3.6 & 1.4 & 4.9 \\
\end{tabular} \\
\hline 15 & Vympel - press & \begin{tabular}{|l|l|l|l|l|l|l|l|l|l|l|}
6.2 & 5.7 & 3.1 & 9.9 & 8.7 & 4.9 & 7.1 & 5.9 & 8.9 & 8.1 & 7.1 \\
\end{tabular} \\
\hline 16 & uzova E.K. & \begin{tabular}{|l|l|l|l|l|l|l|l|l|l|l|}
4.9 & 4.1 & 6.4 & 9.9 & 4.9 & 7.1 & 8.3 & 4.2 & 4.7 & 8.6 & 6.4 \\
\end{tabular} \\
\hline 17 & Polushkin S.G. & \begin{tabular}{|l|l|l|l|l|l|l|l|l|l|l|}
3.8 & 2.9 & 2.7 & 5.6 & 6.4 & 5.9 & 4.1 & 2.6 & 8.2 & 2.5 & 4.9 \\
\end{tabular} \\
\hline 18 & Perfect printing house & \begin{tabular}{|l|l|l|l|l|l|l|l|l|l|l|}
10 & 10 & 10 & 10 & 10 & 10 & 10 & 10 & 10 & 10 & 10 \\
\end{tabular} \\
\hline
\end{tabular}

We have introduced the term "perfect printing house" in order to present the methodological analysis.

"Perfect printing house" is an enterprise of the printing industry, which the consumer would choose among the rest enterprises in the market. This assumption is necessary for the maximum objectification of the research. However, we understand that "perfect printing house" does not exist in reality. "Perfect printing house" is a combination of levels of all elements of the study preferred by the consumer. The introduction of the term "perfect printing house" is necessary due to the requirement to examine the question what kind of expectations of printing industry products consumers have. A study was carried out through the identification of the needs of consumers with the perception of the "perfect printing house".

The next step of perceptual mapping method is to identify the names of.

Identifying correlation estimates on the characteristics of the objects of research (printing houses) with the elements allows to call the axis of the most correlated factors with the elements. Let's represent the data using factor loadings (Table 3).

The model of factors built in the study underlines the importance of the management quality of printing houses, working in the market, as well as the quality of printed products. That is why let's call the axis in accordance with these elements: quality of management and staff qualification (axis 1) and the quality of printed products (axis 2).

Interpretation of the map begins with a study of the location and the company's position relative to the ideal point and with respect to the axes of the perceptual map and each other.

Table 3. Names of axes of perceptual map.

\begin{tabular}{|c|c|c|c|}
\hline № & The main components of the brand & $\begin{array}{c}\text { Axis 1: } \\
\text { "Quality } \\
\text { management and } \\
\text { staff } \\
\text { qualification" }\end{array}$ & $\begin{array}{c}\text { Axis 2: } \\
\text { "The quality } \\
\text { of printed } \\
\text { materials" }\end{array}$ \\
\hline $\mathrm{X}_{1}$ & Staff qualification & $\mathbf{0 . 9 2 3}$ & 0.057 \\
\hline $\mathrm{X}_{2}$ & Quality management & $\mathbf{0 . 9 1 2}$ & 0.232 \\
\hline $\mathrm{X}_{3}$ & Equipment & $\mathbf{0 . 9 0 5}$ & -0.078 \\
\hline $\mathrm{X}_{4}$ & Size of constant and loyal customer base & 0.772 & -0.044 \\
\hline $\mathrm{X}_{5}$ & Reputation (goodwill) of enterprise & 0.562 & 0.177 \\
\hline $\mathrm{X}_{6}$ & Staff motivation to improve the quality \\
& of goods & 0.313 & $\mathbf{0 . 8 3 2}$ \\
\hline $\mathrm{X}_{7}$ & $\begin{array}{c}\text { Visual level of printing } \\
\text { product quality }\end{array}$ & 0.127 & $\mathbf{0 . 9 2 5}$ \\
\hline $\mathrm{X}_{8}$ & The range of printing services & 0.769 & 0.256 \\
\hline $\mathrm{X}_{9}$ & The price factor & -0.042 & $\mathbf{0 . 8 1 4}$ \\
\hline $\mathrm{X}_{10}$ & Innovative technologies & 0.779 & 0.120 \\
\hline $\mathrm{X}_{11}$ & Deadlines of printing order & $\mathbf{0 . 8 8 1}$ & 0.150 \\
\hline $\mathrm{X}_{12}$ & Relations with client & 0.716 & 0.188 \\
\hline
\end{tabular}

The map presents visually that only one enterprise is the closest to the "perfect printing house" - "Service Print". However, the distance from the point of "Service Print" to the point of "perfect printing house" is big enough in the perception of customers. It means that there is the need to change the working strategy of "Service Print" in the market. Its leading position in the market is due to the worst competitive position among its competitors, rather than its effective operation in the market, an effective strategy and efficient positioning of the printing press.

"First printing house", LLC "Orma", LLC "Kirov regional printing house", Printing house "Medical Statistics", LLC "Raduga" and Chauzova have unique images and brands. The uniqueness of the image is characterized by the special situation on the map "individual" location, isolation from other companies.

On the map, there are two groups of companies, which are located nearby. These printing houses have cut-throat competition. As you can see from the map the first group consists of the following printing houses: "Forex", Funtikov, LLC "Staraya Vyatka", Papyrin (Kirovo-Chepetsk), Polushkin. The second group is represented by the following enterprises: "Lona", LLC "Vyatka-Info", "Vimpel-Press". 


\section{Perceptual map}

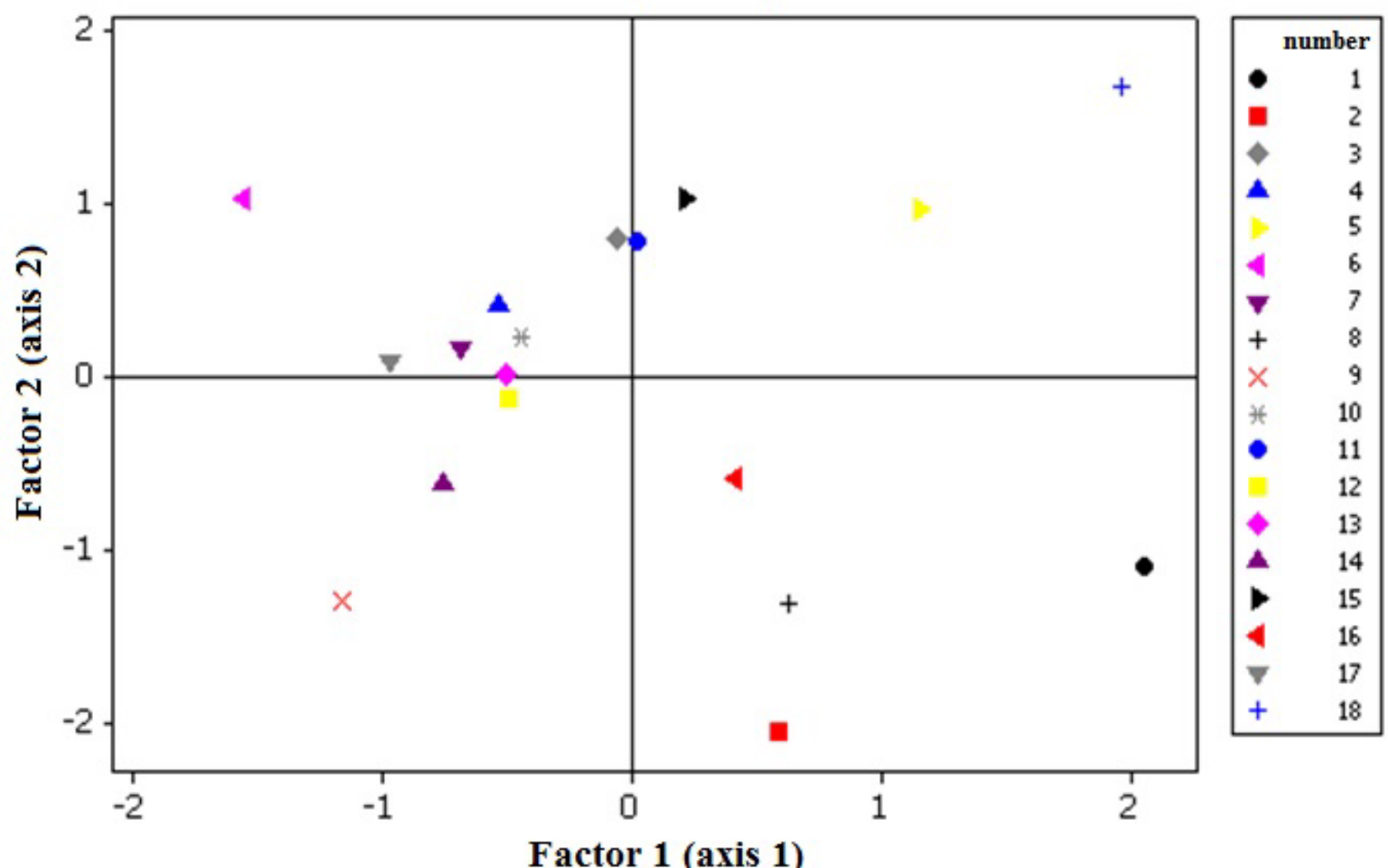

Fig. 1. Perceptual map of competitiveness of printing houses operating in the market of printing services, Kirov.

The outsider in the market for consumers' opinion is the printing house "Medical Statistics" - the state organization, its the target audience is all hospitals, pharmacies and other health care institutions of the Kirov region. That is why orders of other customers of printing services are not fixed for the enterprise and are made according to "residual" principle.

White space on the map indicates the potential for the introduction of new brands on the market or changes in existing businesses positioning.

Printing houses which are far from the beginning of the axes are strong according to the characteristics of printing houses. Thus, LLC "First printing house" is the most powerful on the characteristics of "the quality of management and qualified personnel". It is followed by "Service Print", LLC "Raduga", LLC "Kirov regional printing house" and then comes Chauzova.

However, "First printing house" has weak competitive parameters on the characteristics of the "quality of printed materials".

The following printing houses: "Service Print", "Vimpel Press» and «Orma» have a strong position on the characteristic of "the quality of printed products".

"Service Print" has the strongest position in the framework of the perception of the brand, taking into account its strong position in both directions of the axes.

\section{Discussions}

The results of the present study show a visualization of business on the perception of printing houses brands. It should be emphasized that the brand of enterprises of the printing industry is a complex and dynamic multistructural element of the printing industry enterprises. This is due to a large share of the emotional component in the perception of the printing house brand $[4,6,7]$.

It should be noted that each individual enterprise of printing industry needs to evaluate its brand, as well as to take into account the current market conditions, its market situation. Copying someone's experience is not desirable because it can lead to unpredictable consequences and negative effects.

\section{Conclusion}

This study contributes to the development of brand management of enterprises of the printing industry. The practical application of the research is in the possibility and necessity to use methodical bases of perceptual mapping of the enterprises of the printing industry and to ensure their sustainable development in difficult conditions of the modern market. 
The authors suggest that further studies should be carried out within the framework of the formation of the development strategy of the enterprises of the printing industry on the basis of perceptual mapping.

\section{References}

1. T.A. Burtseva, M.L. Khalyavina, Bulletin of the Altai State Agrarian university, 12(122), 173-178 (2014)

2. T.A. Burtseva, A.Yu. Marinina, Consumer loyalty on the market of consulting services. Marketing, 1(116), 79-84 (2011)

3. O.N. Sinitsyna, I.V. Kultysheva, Modern advertising technologies: theory and practice. Materials of the II Int. scientific-practical conference (part-time), 79-85 (2011)

4. V.S. Matyushkin, Perceptual map as a basis of development of brand communication campaign. Advertising: Theory and Practice, 1, 30-36 (2016)

5. E.V. Lagodina, Europen Social Science Journal, 72(46), 48-54 (2014)

6. L.M. Kapustina, E.A. Zhad'ko, Application of perceptual maps-schemes for the comparative ranking of educational institutions. Proceedings of the Ural State Economic University, 6(50), 113-117 (2013)

7. I. Skorobogatykh, Technique of perceptual mapping. Marketing and Market Research, 5, 2-7 (2004)

8. V.N. Naumov, Estimates of positioning brands on perceptual maps. Marketing and Market Research, 6, 530-540 (2006)

9. D.V. Dmitriev, Yu.Yu. Dmitrieva, Application of three-dimensional effects to improve pervceptual maps. Interexpo Kye-Siberia, 1(1-2), 121-125 (2012)

10. A.A. Sozinova, P.A. Kalinin, Marketing competence as a success factor for printing companies. In the world of scientific discovery, 5.8(65), 3084-3097 (2015). DOI: 10.12731/wsd-2015-5.8-21.

11. A.A. Sozinova, Marketing laws of market development of advertising services. In the world of scientific discovery, 5.2(53), 830-835 (2014)

12. A.A. Sozinova, O.V. Fokina, Mediterranean Journal of Social Sciences MCSER Publishing, 6, 4 S1, 139145 (2015). DOI:10.5901/mjss.2015.v6n4s1p.

13. A.A. Sozinova, O.V. Fokina, Life Science Journal, 11(7s), 318-321

(2014). http://www.lifesciencesite.com.67.

14. A.A. Sozinova, I.V. Androsova, V.L. Abramov, E.A. Tikhomirov, D.V. Redin, T.L. Oganesyan, International Review Of Management And Marketing, 6(S1), 250-254 (2016)

15. E.V. Karanina, I.V. Bykova, N.N. Ilysheva, American Journal of Scientific Research, 1-14, 112122 (2014)

16. N. Ilysheva, E. Karanina, I. Bykova, Special Issue Mediterranean Journal of Social Sciences, 6, 5(S4), $348-355 \quad(2015)$.
$10.5901 /$ mjss.2015.v6n5s4p348

17. A.A. Sozinova, E.V. Zhelnina, V.V. Prokhorova, M.V. Zelinskaya, I.N. Putilina, International Journal of Economics and Financial Issues, 6(S1), 52-56 (2016)

18. V.S. Novikov, A.I. Pykhtin, M.A. Gureva, A.A. Sozinova, M.P. Prokhorova, International Journal of Economics and Financial Issues, 6(S1), 126-132 (2016)

19. N.R. Saenko, A.A. Sozinova, I.S. Karabulatova, I.V. Akhmetov, O.V. Mamatelashvili, E.E. Pismennaya, International Review Of Management And Marketing, 6(S1), 267-272 (2016)

20. N.N. Kataeva, O.V. Fokina, Economics and Management: Problems and Solutions, 2(8), 186-188 (2016) 